\title{
The Impact of Engagement in STEM Activities on Primary Pre- service Teachers' Conceptualization of STEM and Knowledge of STEM Pedagogy
}

\author{
Mehmet Aydeniz ${ }^{\mathrm{a}}$, Kader Bilican ${ }^{\mathrm{b}}$ \\ ${ }^{a}$ The University of Tennessee, USA; ${ }^{b}$ Krr kkale University, TURKEY
}

\begin{abstract}
The purpose of current study was to explore the weaknesses and strengths in pre-service primary teachers' (PST) conceptualization of STEM and their knowledge of STEM pedagogy after engaging in integrated STEM (science, technology, mathematics and engineering) activities for one semester. The course activities emphasized concepts related to engineering design process, the interrelatedness of STEM subjects, inquiry and problem solving. The integrated STEM activities were implemented for six weeks. Data were collected through a questionnaire, reflection papers, semi-structured interviews with a sub set of participants $(n=8 / 20)$. Results show that engaging students in immersive STEM activities helped PSTs develop foundational knowledge regarding STEM, engineering design and STEM pedagogy, which they could built on later to more effectively teach through STEM integration. Discussion focuses on how PSTs and practicing teachers can be supported through sustained professional development for STEM integration pedagogy.
\end{abstract}

Keywords: Engineering, science, pre-service teachers, professional development, STEM

\section{Introduction}

STEM education has dominated the educational reform discourse in the last few years all over the developed and developing countries. As a result, public schools from pre- $K$ to high schools have adopted the demand of this discourse and looking for ways to teach STEM subjects through an integrated approach. While the demand to teach STEM subjects through an integrated fashion across k-12 education has intensified, case studies from classrooms suggest that teachers have limited understanding of integrated STEM and STEM pedagogy (Honey, Pearson, \& Schweingruber, 2014). More, when they attempt to teach science through integration, they face unique difficulties. These observations have motivated science educators to investigate and characterize teachers' conceptions of STEM, and the unique challenges teachers face when teaching through integration. In this study, we report findings of a study in which we attempted to improve pre-service primary school teachers' conceptual understanding of STEM integration and their pedagogical knowledge of STEM though immersive STEM integration activities. The research question we pursued was:

- What are the weaknesses and strengths associated primary teachers' conceptions of STEM integration and STEM pedagogy after engaging in integrated STEM activities for one semester?

\footnotetext{
${ }^{1}$ Corresponding author. A 408 Jane \& David Bailey Education Complex 1126 Volunteer Blvd, Knoxville, TN 37996-3442, Email: maydeniz@utk.edu Aydeniz, M., \& Bilican, K. (2018). The Impact of Engagement in STEM Activities on Primary Pre-service Teachers' Conceptualization of STEM and Knowledge of STEM Pedagogy. Journal of Research in STEM Education, 4(2), 213-234
} 


\section{Significance of the Study}

While there are several studies that focus on teachers' conceptions of STEM integration and their pedagogical knowledge of STEM. Most STEM integration studies in the current literature related to teacher learning have been conducted in the United States (Guzey et al, 2016; Honey, Pearson, \& Schweingruber, 2014; Kim and Bolger, 2017; Wang, Moore, Roehrig, \& Park, 2011). Moreover, even then sufficient effort has not been devoted to primary science teachers' conceptions and pedagogical knowledge of STEM integration. However, research studies show that students start to develop conceptions about STEM at young ages. Considering the importance of early experiences on students' conceptions and identities related to STEM (McCoach et al., 2006; Sullivan, 2016; Tippet \& Milford, 2017), primary teachers' conceptions of STEM and pedagogical knowledge of STEM merits attention and further inquiry.

\section{Review of Relevant Literature}

\section{Conceptualization of STEM}

The term STEM has been used widely among education, industrial and policy communities. Policy makers and industry leaders use STEM to emphasize the importance of a population that is educated in any of the STEM fields. In educational context, however, the term STEM refers to the teaching of STEM subjects in an integrated fashion. This can happen in different combinations. For some, integration of engineering design and technology is sufficient for an activity or curriculum to be called STEM, for others, it refers to the inclusion of all four STEM subjects in the curriculum or a specific lesson. Mobley (2015) defines Integrated STEM as:

An approach to teaching and learning in which any combination of the four major STEM disciplines is taught in a manner such that the curriculum and content of the individual disciplines seamlessly merge into real-world experiences contextually consistent with authentic problems and applications in STEM careers. Such integration includes close and intentional attention to the inclusion of core disciplinary practices of each STEM domain being integrated, and purposeful attempt to make meaningful connections between the core concepts of each discipline, with the goal of using this integrated knowledge to solve real-world problems (p.14).

Sanders (2008) argue that integrated STEM learning experiences must include technological and engineering design as a basis for making connections between concepts and practices of science and mathematics. While there is no consensus on what STEM means, integration of more than one subject, active engagement of students in authentic, design-based learning tasks, reasoning through sustained inquiry and application of STEM knowledge and skills in real-world contexts to solve a problem, through student-centered, constructivist and collaborative pedagogies is key to STEM integration. However, rarely has the focus on problem solving and inquiry has been made explicit in our discourse. More often, it is not the problem solving and inquiry that gets discussed but the inclusion of engineering and the integration of STEM subjects.

\section{Review of Studies on STEM Pedagogy}

Since its popularization in 2000s several STEM educators have conducted studies related to integrated STEM education (Cervetti, Barber, Dorph, Pearson, \& Goldschmidt, 2012; Guzey et al., 2016; Harwell, Philips, Mareno, Guzey, Moore, 2015; Lam, Alviar-Martin, Adler \& Sim, 2013; Lederman \& Lederman, 2013; Roehrig, Moore, Wang \& Park, 2012). While some studies have attempted to explore the potential benefits of integrated STEM for students' learning outcomes (Childress, 1996; Guzey et al., 2016; Riskowski, Todd, Wee, Dark \& Harbor, 2009)), others have focused on the challenges faced by STEM teachers to teach science through an integrated framework (Lam et al, 2013; Lehman, Kim, \& Harris, 2014) Studies that focus on learning outcomes, maintain that learning science through an integrated fashion improves students' problem solving skills, their critical thinking skills, collaboration skills and results in better conceptual understanding. However, whether 
these reported benefits are significantly different from learning science through a single subject approach or not begs further empirical support.

While many benefits of STEM integration have been advocated, teachers struggle to buy into the idea of teaching through an integrated fashion. Further, even when they are convinced of the value of integration, they have limited experiences with learning through STEM integration or lack pedagogical knowledge to teach through integration (Ring et al., 2017). The fundamental challenges associated with teaching through an integrated fashion include: teachers' resistance to teach through an integrated fashion (attitudinal) because of lack of or limited experiences (Frykholm \& Glasson, 2005; Gresnigt, Taconis, van Keulen, Gravemeijer \& Baartman, 2014), teachers' belief that teaching through integrated fashion compromises students' conceptual understanding of core subject content (Estapa \&Tan, 2017), lack of resources to teach through an integrated fashion, teachers' lack of knowledge and experiences in engineering and technology, and lack of time for shared planning (Lederman \& Lederman, 2013; Yeung \&Lam, 2007). Collectively, these studies suggest that: 1) teachers hold naïve conceptions related to STEM integration, 2) teachers do not hold adequate pedagogical knowledge and skills to teach through STEM integration, and 3) consequently, teachers are not well prepared to implement integrated STEM curriculum in their classrooms. If this is the case, then teacher educators should assume the responsibility to make a difference in teachers' conceptions of STEM and promote their students' acquisition of pedagogical knowledge related to STEM integration through effective interventions. The first step in accomplishing this goal would be to measure PST's conceptions of STEM, and their pedagogical knowledge related to STEM integration. Such an approach will help us identify problematic areas related to pre-service teachers' conceptions of STEM and their pedagogical knowledge related to STEM integration and address them before they enter the classroom.

\section{Review of Empirical Studies on Student Learning in STEM}

STEM integration is believed to increase student motivation, engagement, learning and interest to pursue STEM careers (Moore, 2008). Proponents of STEM integration argue, these utcomes are possible because STEM integration engages students in solution to real-world problems, in a culturally relevant way by requiring them to draw from content knowledge and practices across from different disciplines (Moore, 2008). Since its popularization as a pedagogical approach to teaching science and mathematics, several scholars have explored impact of STEM on student learning, engagement and attitudes, however, not all of these studies report a significantly positive impact rsulting from students' participation in integrated STEM activities.

Wendell and Rogers (2013) conducted a study with middle school students and reported differential effects of integrated STEM on student learning. They exposed students to two different integrated STEM activities. In the first activity, students completed a LEGO-based engineering unit on sound, and in the second activity students completed a LEGO-based engineering unit on simple machines. Interestingly, they found that the students who completed the engineering unit on simple machines developed statistically significant and greater learning gains than those who learned science business as usual. However, authors did not observe the same positive effects on student learning for the sound unit. This suggest that the context in which integration takes place influences the effectiveness of integrated curriculum on student learning. This finding is consistent with other studies that emphasize the importance of context on reported learning outcomes in educational studies (Bennet \&Holman, 2002; Trigwell \& Prosser, 1991).

LaChapelle et al. (2011) measured the impact of engineering design on students' conceptual understanding. The treatment group in their study completed a unit on organisms through engineering. The control group on the other hand completed a unit only on organisms. They found that the engineering unit did not produce statistically significant impacts on student learning as measured through a post-science content test. More recently, Guzey, Moore, Harwell \& Moreno (2016) explored the effects of an engineering unit on middle school students' conceptual understanding and attitudes in three life science classrooms. Three middle school science teachers and 275 seventh grade students participated in the study. Students were engaged in design-based STEM activities for over 15 class of 50 minutes each. The teachers who taught the courses had gone 
through a rigorous professional development program that consisted of three-week long summer workshops and ongoing professional development throughout school year. The teachers implemented a unit that they had collectively developed during the summer professional development. The authors measured the impact of these activities on students conceptual understanding of science and mathematics. They found that the integrated STEM curriculum did not have a statistically significant effect on students' learning in the domains of science and mathematics.

As the results of these studies indicate, despite lack of consistent and rigorous evidence for effectiveness of STEM integration on student learning, school districts continue to push for integrated STEM curriculum. This demand from schools creates significant need for teachers to develop pedagogical knowledge and skills to teach science through STEM integration. Yet, only few pre-service science teacher education programs across the world are making STEM integration as part of their curriculum. We provide a review of some of these interventions and the impacts they have had on teachers' conceptions and pedagogical knowledge related to engineering.

\section{Review of Empirical Studies on Teaching through STEM Integration}

Kim and Bolger (2017) investigated the impact of lesson planning on pre-service teachers' confidence in teaching through STEAM. The participants of this study were 119 pre-service elementary teachers. After exposing the participants to the theory behind STEAM framework and STEAM-based teaching and learning through a two-hour lecture, researchers guided participants to develop a STEAM lesson plan for the subsequent five weeks. After the participants developed their initial lessons, they exchanged lessons and received feedback from each other in class. The students kept working on their lesson plans for the rest of the class and received feedback from their instructor. Finally, they presented their lessons to their classmates through microteaching at the conclusion of the class, the authors found that the act of lesson planning, revision and presentations resulted in increased "awareness, perceived ability, value, and commitment for STEAM" among participants (p. 600). More important, the PSTs thought that an integrated STEAM curriculum would "foster high-level thinking among their future students." (p. 602). Despite these reported positive effects, the authors also found that pre-service teachers experienced significant challenge to develop STEAM lessons. More specifically, they found that PSTs found it difficult to make connections between different components of STEAM. The authors attribute this difficulty to PST's lack of experiences in "looking across subjects to integrate ideas" (p.602). As a result, "they needed guidance to ensure that integrated topics were all addressing learning objectives at the appropriate grade level" (p. 602). This observation is important and point to the complexity of enternatining multiple goals related to content, practice, and skills when planning and teaching integrated STEM lessons.

In a recent study conducted with PSTs in the United States, Estapa and Tank (2017) found that when PSTs received support from engineering graduate students, they were able to come up with a "large number and variety of engineering concepts" that could be connected to the target design activity. The authors analyzed lesson plans designed by each of the 10 triads and found that only few lessons explicitly made references to science or math content goals. More, when the authors observed their lessons in action they observed that "the content learning focused mostly on engineering design and skills or practices, such as teamwork" rather than science and math content. Clearly, this is a problem for elementary STEM teachers. While design-based activities help students acquire invaluable engineering design skills, without explicit attention to content standards, STEM integration cannot result in intended outcomes.

Stohlmann et al. (2012) studied four middle school teachers' implementation of an integrated STEM curriculum. While they report that, "The teachers were not focused on lecturing, but on having students work together and develop their own ideas, they had difficulties knowing how long lessons would last and knowing how to best guide students in their work" (p. 31). They emphasize several areas of concern expressed by four teachers teaching in an integrated STEM framework in the study. The first observation was teachers' obsession with controlling the learning environment. They found that because integrated STEM teaching priorities student ownership and autonomy over learning goals, activities and outcomes, teachers become nervous 
about the content and process of learning. Second, they found that provision of sufficient resources necessary for students to pursue their induvial projects (i.e., to design, test, and revise solutions to problems) becomes problematic (Stohlmann et al., 2012, p. 30). The topic of necessary resources to teach through integrated STEM has been reported in other studies as well. These studies emphasize that teachers' confidence in their ability to implement integrated lesson plans were directly associated with availability of relevant and ready to use curricular materials (Guzey, Nyachwaya, Moore, \& Roehrig, 2014; Mobley, 2015) and time to develop and teach lessons. For instance, Mobley (2015) found that teachers were concerned about time to collaborate with other STEM teachers to design lessons, lack of classroom time to implement integrated STEM lessons with maximum fidelity and support for learning about ways to teach integrated STEM lessons in an effective manner.

Collectively, these studies suggest that teachers need a special type of pedagogical knowledge, time and resources for planning and teaching integrated STEM lessons. However, we do not know precisely what this type of knowledge might look like, and how to go about helping STEM teachers to develop such knowledge and skills to teach STEM lessons with limited resources and within the confines of traditional school bell schedule. This is especially true for novice teachers who enter the classroom with the expectations and demands related to STEM integration. Therefore, engaging preservice teachers in immersive activities in which they are given the opportunity to question, reflect on and discuss their conceptualization of STEM, as well as experience STEM -based learning activities and collaboratively design lessons through an integrated framework becomes very important. These experiences can help them become aware of the problems with their conceptualizations of STEM, the challenges associated with designing STEM-based lessons, and plan accordingly. In this study, we explore these issues through a qualitative approach. The driving question for this study is:

- What are the weaknesses and strengths associated primary teachers' conceptions of STEM integration and STEM pedagogy after engaging in integrated STEM activities for one semester?

\section{Methodology}

Consistent with the exploratory nature of this study, we adopted a qualitative approach for studying PST's experiences with immersive STEM activities. Our approach is rooted in the Interpretivist epistemology, which aims to interpret human experiences and interactions within the relevant context (Crotty, 1998). Interpretivist approaches rely on contextually revelatory methods such as interviews, and content analyses of relevant documents and observations (Guba \& Lincoln, 1994). This approach is suitable for this study because, we are interested in exploring issues with PST's conceptualization of STEM, and problems with their pedagogical knowledge related to STEM education.

\section{Participants}

Participants of the study were 20 ( 17 females, 3 males) sophomore primary pre-service teachers (PST). All of the participants were attending their third semester at a primary science education program in Turkey. The study took place in the first science laboratory course that these participants took as part of their program. Most of them had rarely engaged in inquiry-based science learning or had taken any inquiry-based science courses either at college or during their k-12 educational experiences prior to taking this course. Most of their science learning experiences were limited to teacher-centered instruction and not any experiences related to STEM integration. Within the primary teacher education program, they took general science courses such as introduction to physics, chemistry and biology in their first three semesters of their program from content experts. They took the science laboratory course, the context of this study, at the third semester of the primary teacher education program. The class was heavily focused on application of science process skills in conducting inquiry based experiments. The course's overall goal was to provide students with first hand-on experiences about basic concepts of chemistry, biology and physics through inquiry-based methods. 


\section{Intervention}

The intervention started at the sixth week of the science laboratory course mentioned aboive. The participants were engaged in inquiry based laboratory activities during the first 6 weeks of the class. The rest of the class was devoted to helping pre-service teachers to understand and experience the concept of integrated STEM and pedagogical approaches implemented in integrated STEM contexts. First, we introduced the participants to the field of engineering through expert visits to the class and engaged participants in some basic engineering activities introduced by the epxerts (i.e., engineering faculty). Then, pre-service teachers were engaged in STEM tasks to realize and practice teaching of science content in an integrated way by using engineering design processes.

The intervention started with a visit of a faculty member from mechanical engineering department of the same university. The faculty member's talk focused on engineering practices in the context of mechanical engineering and how engineers think about problems and design solutions. The second author, also the instructor of the course intervened as the context demanded, and attempted to help students connect the points highlighted by the guest speaker to engineering design processes explicitly. Then, pre-service primary teachers visited a mechanical engineering laboratory, to get a concrete picture of the types of research that mechanical engineers do. They asked questions and received answers related to nature of the work of mechanical engineers.

At the second week, another colleague from computer engineering department visited the class and gave a talk about what computer engineers do, how they think and approach solutions to the problems that interest them. The main aim of these visits from other engineering departments was to familiarize participants with engineering practices, and help them conceptualize engineering design process. At the end of his lecture, he conducted a coding activity with the participants. He walked the students through a basic coding activity using phyton (a programming language).

At the end of these visits, participants were required to reflect on and write down how these visits contributed to their understanding of engineering practices, and their understanding of the relationships between different components of S-T-E-M. They were also required to make connections between ideas discussed during the guest lectures and teaching STEM in an integrated manner, with an explicit focus on engineering design. After the students were introduced to the concepts of engineering, they participated in three integrated STEM activities. Each task was accompanied by some guiding questions drawing students' attention to the S-T-E-M components and specifically engineering design. The guiding questions that preservice teachers were required to think about were; "what is the science content in the task?", "how is this task related to math, where is the technology and engineering design in this activity?", and "when and how did you use engineering design in this task?"

The first activity that the students engaged in was the egg drop challenge. The activity took two weeks. Participants worked in groups, in the first week they decided on their proposed design solution to the problem and the design of their prototype. The following week, each group tested their design in class, then each group discussed the success and failure of their designs in their groups. After, testing of the prototypes, the students were guided to discuss the pedagogical issues related to the implementation of this STEM activity in their future classrooms. First, participants were encouraged to discuss how this STEM activity differed from a regular inquiry-based laboratory activity. Then, the researcher highlighted the engineering design processes that participants experienced while completing the task. Participants were expected and guided to discuss the engineering design component in the tasks they engaged in and desigend. Finally, participants were asked to connect related activity with science curriculum that they are expected to teach after graduation.

The participants were then provided with the second STEM activity called twirly activity (Savran \& Gencer, 2015). The activity aimed to differentiate science and engineering practices by providing a context in which participants conducted a scientific investigation. At the end of the task, participants filled an activity worksheet which included such questions as how the activity is related science and mathematics, how their 
prototype worked and what features of the scientific investigation they participated in while competing the learning task. The course instructor facilitated an intergroup discussion about the content of their group work and discussions. During week five, participants engaged in the "baking soda and vinegar powered car" STEM activity (https://sciencing.com/make-car-baking-soda-vinegar-6498045.html ). The professor posted a question related to constructing a car that worked without gas the week before this activity. Then, participants were asked to come up with design ideas regarding construction of a car that worked without fossil fuels. The participants tested their ideas and made a final design of their prototype in the following week. Similarly, after the activity, the professor facilitated a class discussion about the engineering design processes that they used while completing this activity and asked them to reflect on connections to teaching integrated STEM lessons. Moreover, the participants were required to fill in the activity sheet in which discussion questions were provided and participants were required to respond individually. During week six, participants were asked to design a STEM lesson as a capstone assignment for the course. Participants could choose any science content but were required to connect the designed activity to the Turkish National Science Standards. In addition, they were asked to explicate how the task reflected engineering design processes. The summary of our intervention is provided in Table 1.

Table 1.

Summary of Intervention

\begin{tabular}{|c|c|c|c|c|}
\hline WEEK & Activity & Purpose & Nature of the Activity & Length \\
\hline WEEK 1 & $\begin{array}{l}\text { Mechanical } \\
\text { Engineering } \\
\text { Faculty } \\
\text { Visit/Visit to } \\
\text { laboratories } \\
\text { of Mechanical } \\
\text { Engineering } \\
\text { Department }\end{array}$ & $\begin{array}{l}\text { To help students understand the } \\
\text { work of engineers. } \\
\text { To help students gain perspective on } \\
\text { the types of problems mechanical } \\
\text { engineers work on and the ways } \\
\text { in which they go about designing } \\
\text { solutions. } \\
\text { To help students understand the } \\
\text { engineering design processes. }\end{array}$ & $\begin{array}{l}\text { Lecture/guided tour of } \\
\text { the lab. } \\
\text { Questions\&Answers } \\
\text { Reflection on the expe- } \\
\text { rience. }\end{array}$ & 3 Hours \\
\hline WEEK 2 & $\begin{array}{l}\text { Computer } \\
\text { Engineering } \\
\text { Faculty visit / } \\
\text { Coding activity }\end{array}$ & $\begin{array}{l}\text { To help students understand the } \\
\text { work of engineers. } \\
\text { To help students gain perspective } \\
\text { on the types of problems computer } \\
\text { engineers work on and the ways } \\
\text { in which they go about designing } \\
\text { solutions. }\end{array}$ & $\begin{array}{l}\text { Lecture/ } \\
\text { Guided hands-on cod- } \\
\text { ing activity. } \\
\text { Questions/Self } \\
\text { reflection }\end{array}$ & 3 hours \\
\hline $\begin{array}{l}\text { WEEK2 } \\
\& \\
\text { WEEK3 }\end{array}$ & $\begin{array}{l}\text { Egg drop } \\
\text { challenge Twirly } \\
\text { Activity }\end{array}$ & $\begin{array}{l}\text { To engage in problem solving. } \\
\text { To differentiate science and } \\
\text { engineering practices. } \\
\text { To think about the integrated nature } \\
\text { of science, math and engineering. }\end{array}$ & $\begin{array}{l}\text { Student initiated } \\
\text { / inquiry based } \\
\text { engineering design } \\
\text { activity }\end{array}$ & $\begin{array}{l}2 \text { weeks/ } \\
6 \text { hours }\end{array}$ \\
\hline WEEK 4 & $\begin{array}{l}\text { Baking soda and } \\
\text { vinegar powered } \\
\text { car }\end{array}$ & $\begin{array}{l}\text { To experience engineering design } \\
\text { processes } \\
\text { To engage in inquiry-based learning } \\
\text { To engage in problem solving. } \\
\text { To understand the connections } \\
\text { between STEM content and } \\
\text { practices. }\end{array}$ & $\begin{array}{l}\text { Student iniated/ } \\
\text { inquiry based } \\
\text { engineering design } \\
\text { activity }\end{array}$ & $\begin{array}{l}\text { 1Week / } 3 \\
\text { hours }\end{array}$ \\
\hline
\end{tabular}




$\begin{array}{lll}\text { WEEK 5 } & \begin{array}{l}\text { Preparation and } \\ \text { presentation } \\ \text { of integrated } \\ \text { STEM activity }\end{array} & \begin{array}{l}\text { To see if the students can design } \\ \text { integrated STEM-based learning } \\ \text { activities. }\end{array} \\ \text { WEEK6 } & \end{array}$

Student iniated/, inquiry based, 2Week / 6 hours engineering design activity

\section{Data and Data Collection}

Data were collected through qualitative data collection methods. Data consisted of participants' responses to an open-ended questionnaire, post interviews, and written reflection papers after guest lectures. All participants were asked to answer questions on the open-ended questionnaire (see Appendix A) regarding their conceptualizations of STEM, STEM pedagogy, engineering design, pedagogy of engineering design, and challenges related to teaching STEM through an integrated manner. While we administered the questionnaire both before and at the conclusion of intervention, we primarily relied on the post-intervention responses, because participants held very naïve conceptions, gave very short responses and could not elaborate on their responses on the pre-test.

In addition to the open-ended questionnaire, we conducted post interviews with eight participants who volunteered to be interviewed. These interviews were audio -recorded. The interviews were semi-structured and participants were asked to elaborate on their responses given in the questionnaire. The purpose of these interviews was to get an in-depth understanding of participants' conceptualization of STEM, STEM pedagogy, engineering design process and pedagogy of integrating engineering design into their STEM lessons.

\section{Data Analysis}

We primarily relied on content analysis methods in analyzing our data. Data analysis consisted of content analysis of PSTs' responses to the open-ended STEM integration survey, interview transcripts and reflection papers. Content analysis methods requires systematically analyzing evidentiary materials and reduce findings to pre-conceived categories to describe the phenomenon (Mostyn, 1980).

In our analyses, we did not focus on comparison of pre- and post-questionnaire responses, rather we only focused on analyzing PSTs' post-questionnaire responses, reflection papers and the results of interviews with a subset of PSTs $(n=8)$. This method was adopted because instead of focusing on the effectiveness of our intervention, we were most interested in identifying the weaknesses and strengths in PSTs conceptions and knowledge related to STEM integration after we provided them relevant integrated STEM experiences. This approach we think offers valuable insight about the needs of PSTs related to STEM integration because participants held naïve conceptions about what integrated STEM meant at the beginning. They made an attempt to conceptualize what integrated STEM might mean at the beginning but heir initial conceptualizations focused only on the integration of math and science, and some participants left the answer sections blank. So, the quality of evidence provided on the pre-test questionnaire was very low and did not allow for meaningful comparision of pre and post.

We defined preliminary broad coding themes based on the purpose of our study, and the questions we had asked of the participants in our questionnaire, interviews and reflection papers. These initial categories were further solidified, modified or refined through triangulation across different data sources (Miles \& Huberman, 1994). While most themes were dictated by our questionnaire and interview questions, we continually revisited, refuted, revised, modified and added new themes as our analysis across different data sources progressed. Through this iterative process, common and consistent themes emerged across our data. These themes include: STEM conceptualization and justification, STEM pedagogy, perceived benefits of teaching through integrated stem, conceptions of teaching through engineering design, justifications for teaching through engineering, challenges experienced while designing integrated STEM, resources needed to teach integrated STEM. 
The data analysis was conducted by the two authors and involved several steps. First, each author independently read participants' responses to the questionnaire, and content of participants' responses to the interview questions. Our goal in this stage was to categorize participant's responses to the pre-determined themes, add additional themes if emerged from the data, and make sense of students' responses. Second, the authors met to discuss their categorization of the themes, and address differences in their interpretations of participants' responses and come to a consensus about the categories and perceived meaning of participants' responses. Finally, participants' responses were categorized as being relatively more sophisticated to relatively less sophisticated. For instance, sophistication of participants' answers related to STEM was determined based on the intentional integration, focus on engineering design, problem solving, creativity and elaboration on their reasoning for this category.

\section{Results}

We present results in the following order: participants' conceptualization of STEM, knowledge of STEM pedagogy, perceived benefits of teaching through STEM integration, conceptions of teaching through engineering design, justifications for teaching through engineering design, participants' understanding of pedagogical demands of STEM integration and resources needed for teaching science through STEM integration. The results of our analyses are reported in the following sections.

\section{Participants' Conceptualization of STEM}

The results of our analyses indicate that participants' provided informed answers related to their conceptualization of STEM. Not only did the participants provided elaborate answers but they also made references to creativity, problem solving, design-based solutions and intentional integration of concepts. Despite such an improvement, the sophistication level of participants' conceptualization of STEM varied from one participant to the other participant.

Table 2.

Definitions and Justification of STEM Integration

\begin{tabular}{lll}
\hline & Themes & Frequency \\
\hline & Integration of subjects & 17 \\
& Intentional integration of subjects & 16 \\
& Problem solving through design & 16 \\
STEM Definition \& & It makes problem solving easier & 17 \\
justification & This how scientists/engineers work in real life/lab situa- & 15 \\
& tions. & 17 \\
& Preparing students for 21 & \\
& &
\end{tabular}

We provide exemplary answers below. One participant defined STEM as:

STEM refers to the intentional effort to integrate and teach math and science concepts through engineering and technology in the classroom. STEM is often taught through integration and hands on activities, and problem-based scenarios. STEM concepts should be taught through integration because all of these fields are connected. Engineering is problem solving through design, mathematics is doing calculations and science is about inquiry. I said engineering is about problem solving. An electrical engineer has to use math and science to develop better solutions to the problems at hand. To solve problems, engineers need to brainstorm and they need to think hard, they need to think creatively, but they also need to use concepts and laws from science, from physics and use math to develop solutions. 
This statement shows the sophistication level of this PST regarding STEM integration. The answer highlights the need for integration of concepts and practices of different fields in solving everyday problems through inquiry.

\section{STEM Pedagogy}

In an effort to understand the weaknesses and strengths in participants' conceptions of STEM pedagogy, we explored participants' conceptions of STEM pedagogy. Surprisingly, most participants provided answers that aligned well with the accepted reform-based practices in STEM education. However, participants struggled with elaborating on details of the strategies they offered or how they may scaffold instruction for maximum student engagement, productivity and learning. The majority of participants made references to the problembased nature of STEM learning, emphasized the importance of engineering design in the learning activities proposed, the inquiry nature of learning, the hands-on nature of STEM activities, helping students to make connections across different STEM fields, and the importance of creating a motivational context for students to engage in problem solving.

Table 3.

Participants' Conceptualizations of STEM Pedagogy

\begin{tabular}{lll}
\hline & Themes & Frequency \\
\hline & Problem-based instruction & 17 \\
& Project based instruction & 9 \\
Design-based instruction & 15 \\
& Creating a context for students to problem solve & 12 \\
& Promoting inquiry & 16 \\
Hands-on activity & 15 \\
& Giving students opportunity to make connections be- & 17 \\
& tween STEM fields & \\
& Giving students opportunity to integrate knowledge for & 16 \\
& solving problems & \\
\hline
\end{tabular}

The following exemplary statements show both the strength and weaknesses in PST's conceptualization of integrated STEM pedagogy. One participant provided the following answer regarding her conception of STEM pedagogy. He said:

We need to teach STEM through hands-on activities, and inquiry-based learning. We need to provide the learning environment and context for students to first explore, and problem solve. The focus of instruction should not be transmission of information to the students from the teacher lecture, it should be about encouraging student inquiry and problem solving. Students will themselves establish the relationships and make connections between the science, chemistry and physics concepts and physics and math concepts when attempting to solve a problem or design a solution. We just need to be able to design rich learning activities for them and support them as they design their solutions. Students learn concepts from physics, from chemistry and math independently but when we engage them in integrated STEM activities, we give them the opportunity not only to make connections between concepts, but also it gives us the opportunity to assess their knowledge of each field together.

This exemplary statement shows that the PST focuses on inquiry-based learning, helping students make connections, design and problem solving. These aspects of instruction are aligned with the type of pedagogical practices associated with STEM integration. 


\section{Perceived Benefits of Teaching through STEM integration}

One of the factors that may play a critical role in mitigating teachers' ability to teach through STEM integration is their views about the perceived benefits of STEM integration. Participants reported several advantages of teaching through integrated STEM. These perceived advantages are reported in Table 4.

Table 4.

Participants' Conceptualizations of STEM Pedagogy

\begin{tabular}{lll}
\hline & Themes & Frequency \\
\hline & Opportunity to assess students' knowledge across & 9 \\
& different subjects & \\
& Helping students to develop problem solving skills & 17 \\
Benefits of teaching through STEM & Fosters student curiosity & 15 \\
& Fosters student creativity & 15 \\
& Help students develop interest in STEM fields & 17 \\
\hline
\end{tabular}

The perceived benefits reported by PSTs ranged from giving the teacher the opportunity to assess students' knowledge and skills across different STEM subjects to fostering students' curiosity, students' creativity to helping them to develop problem solving skills. One participant said:

STEM integration allows the teachers the opportunity to see if the students can transfer and use the knowledge gained from lessons that are taught independently. It encourages the students to develop problem solving skills. It will also foster student creativity and independent thinking because students are faced with a problem case and they are being asked to solve the problem.

As this exemplary statement shows, PSTs were able to see the pedagogical benefits of STEM integration both for teachers and the students. However, most of the PSTs focused on pedagogical benefits of STEM integration for the students.

\section{PST's Conceptions of Teaching through Engineering Design}

Since engineering design is central to STEM integration, we wanted to explore PST's conceptions of teaching through engineering design. The results show that PSTs were able to elaborate on various aspects associated with teaching through engineering design. The themes emerged from participants' answers are provided in Table 5. 
Table 5.

Participants' Conceptualizations of Teaching through Engineering Design

\begin{tabular}{lll}
\hline & Themes & Frequency \\
\hline & Creating a context for students to ask questions & 12 \\
& Promoting design-based thinking & 15 \\
& Engaging students in problem solving & 17 \\
& Encouraging student creativity & 12 \\
& Providing opportunity to test ideas, design solu- & 16 \\
& tions. & \\
& Coming up with alternative solutions & 14 \\
Conception of teaching through & Making observations to determine a problem & 13 \\
& Systems thinking & 9 \\
& Figuring things out & 17 \\
& Making calculations & 11 \\
& Varying variables to make the system work effi- & 13 \\
& ciently or to fit the model. & \\
& Testing: Trial and failure. & 16 \\
& Brainstorming & 15 \\
& Questioning & 13 \\
\hline
\end{tabular}

These results show that PSTs started to build a foundational understanding for teaching STEM through engineering design. We provide exemplary statements provided by one PST regarding her understanding of engineering practices, the engineering nature of her lesson, along with her justification as to why she thinks her lesson is an engineering design-based lesson in Table 6.

Table 6.

Exemplary Answer for Understanding of the Engineering Nature of the Lesson and Justification

\begin{tabular}{|c|c|}
\hline Aspect & Participant's Answer \\
\hline $\begin{array}{l}\text { Engineering } \\
\text { Practices }\end{array}$ & $\begin{array}{l}\text { When I think ofengineering practices, design thinking, evaluation, testing, making predictions, } \\
\text { making observations, and looking at things from different perspectives, alternative solutions, } \\
\text { come to my mind. When a student looks at a cooler, he /she they only see a cup made up } \\
\text { of aluminum but when they look at its function they see engineering design. Students then } \\
\text { think of all engineering practices and design thinking that has been used by engineers in } \\
\text { designing the cooler. They start to think and ask, What materials we must use?, How we must } \\
\text { use these materials? What design should be use and why? During the engineering design } \\
\text { process, you must identify a problem, develop a tentative solution, test the solution to see } \\
\text { if it serves the function, evaluate the results of the tests, and if it serves the function then } \\
\text { you market the product. The students go through the same processes when they are solving } \\
\text { an engineering problem or designing a solution in the classrooms. They make observations, } \\
\text { they connect the dots by using their creativity, they make predictions, they design, they test, } \\
\text { evaluate and construct. }\end{array}$ \\
\hline
\end{tabular}


My lesson focused on the relationship between pressure and volume and designing a system based on this principal. The students are asked to use this principal to make two balloons to rise faster or slower in the air. We designed two balloons with two different pressures in it and used Torricelli's gas law to see how they rise. This theory has guided the development of many engineering technologies so it is important that students understand that law. Scientists and

Engineering nature of the lesson

Justification as to why this lesson involves engineering design engineers have used this theory to design systems. They have used it in designing perfume cans, in rocket design, in fire extinguishing technologies. Scientists and engineers have used this law and their creativity to solve problems and design products that make our lives better. These examples tell us that the main purpose of engineering design is to design solutions to solve problems. In my activity, we differed the amount of the gas in the balloons and tested to see which balloon would rise faster and discussed the reasons behind our observations and the implications of these observations for designing new products that can meet human needs or simplify their lives.

It is engineering because students build a system, and they brainstorm, they test, they make observations and evaluations, and engage in questioning. For instance, students ask, why do we need to put so much gas in this balloon. They look at the fire extinguisher, they start to think about why is there pressure in these extinguishers? Further, they make observations about the elevation differences between the balloons, they figure out why there is less air pressure at higher elevations. They brainstorm, they interpret they came up with alternative ideas. You try and fail and try again to come up with an idea so it is not easy to design things. Students make observations, build systems, test and fail but during the process they apply their knowledge of science, and learn about the implications of scientific knowledge in engineering design and make connections between gas pressure and some systems such as rockets. I designed my lesson so when the students look at a rocket, they can start to think and relate these concepts to the rocket design. They say that when gas is heated it expand and the kinetic energy of the gas particles increase which then increases the pressure. So to manage the amount of pressure, we need math to do the calculations to adjust the amount of pressure. So my lesson has engineering design and science and math.

As this exemplary answer indicate participants have started to develop an informed understanding of engineering design and how science maybe taught through engineering design.

\section{Justification for Teaching through Engineering Design}

PSTs provided diverse responses as for the justification to teach through engineering design. These justifications ranged from an emphasis on the intellectual capital and professional workforce needed for country's economic prosperity, to its potential pedagogical benefits such as promoting students' systems thinking abilities, encouraging students to develop creative solutions to the problems facing different industries such as medical, environmental, defense and agriculture. 
Table 7.

Justification for Teaching through Engineering Design

\begin{tabular}{lll}
\hline & Themes & Frequency \\
\hline & $\begin{array}{l}\text { Our country needs strong engineers for our econom- } \\
\text { ic prosperity. }\end{array}$ & 17 \\
& It engages students in systems thinking & 14 \\
& $\begin{array}{l}\text { Encouraging creativity: coming up with alternative } \\
\text { solutions. }\end{array}$ & 15 \\
Justification for teaching & $\begin{array}{l}\text { Developing innovative systems/solutions to address } \\
\text { engineering design }\end{array}$ & 15 \\
& $\begin{array}{l}\text { various problems. } \\
\text { Exposing students to the work of engineers/ increas- }\end{array}$ & 17 \\
& ing student interest in engineering fields. & \\
\hline
\end{tabular}

One PST in particular, who we thought demonstrated a sophisticated understanding said the following as justification for teaching engineering design:

Learning through engineering design makes learning more durable and teaches students to think more globally. This result is likely to happen because students learn by doing, and in a context relevant to their lives. Moreover, engineering design forces students to think creatively. When I bring the tools out, students are going to ask: What are we going to do today? They are going to think. When I ask them to design a product, they are going to think about how to put different parts together, think about what their products may look like, this is going to require them to think creatively.

As this exemplary statement shows, most participants were able to cite the pedagogical benefits of teaching STEM through engineering design.

\section{Participants' Understanding of Pedagogical Demands of STEM Integration}

Participants reported unique challenges that they experienced in designing the integrated STEM lessons in the context of this study and the course. Not surprisingly, as expected PSTs cited 1) lack of content knowledge, 2) lack of experience in engineering design, 3) lack of experience in designing integrated STEM lessons, 4) difficulty with coming up with problem cases as impediment to their abilities to design integrated STEM lessons.

Table 8.

Participants' Understanding of Pedagogical Demands of STEM Integration

\begin{tabular}{lll}
\hline & Themes & Frequency \\
\hline & Lack of experience in designing integrated & 17 \\
& lessons. & \\
& Lack of knowledge and experience in engi- & 15 \\
neering design. & \\
Challenges experienced while designing the & Coming up with design-based problem cas- & 17 \\
lesson & es. & \\
& Problem with content knowledge made it & 17 \\
& difficult for me come up with a problem to \\
& make connections across disciplines. & \\
\hline
\end{tabular}

Now that the PSTs had experienced learning through STEM integration and developed an integrated STEM lesson, we wanted to know what types of challenges they experienced during the process of lesson planning and the types of support and resources they thought they would need to become well-prepared for the task of teaching through STEM integration. Participants' experienced unique challenges, however, lack of experience 
with engineering design, lack of content knowledge, and lack of experience with designing integrated STEM lessons were cited to be the main hindrances to their abilities to design integrated STEM lessons. To expose our readers to the details of challenges that two PST's experienced in designing integrated STEM lessons we provide some quotes. One PST said the following regarding the challenges she experienced:

I realized that I have gaps in my knowledge of science and skills in engineering design. I realized that I do not have experience in designing integrated STEM lessons, and to design better lessons, I will need mentorship and more practice. For instance, I initially only had students make observations, test their ideas, and acquire knowledge. I experienced some challenges in making connections to engineering and technology but I still do not think I did a great job with the engineering and technology component of my lesson.

Another PST focused on the conceptual and practical challenges he experienced with integrating engineering design into his lessons.

I experienced the most difficulty with the engineering part. Because when we think of engineering we think of big projects, planes, bridges, we never think of design based thinking. Therefore, I was trying hard to make my students to construct something big but also something practical. It is hard to integrate engineering design in short activities. I also do not know much about the engineering design process myself. I realized that I need to have a more in-depth understanding of both the engineering design process and engineering practices. I need to develop skills needed for me to bring the concepts down to their level of understanding and skill levels. Not only do I need to understand the engineering design process but I also need to develop pedagogical knowledge needed for me to teach these skills to my students in an effective way.

These two exemplary statements show the unique challenges each PST experienced both conceptually and practically in designing engineering-based lessons. Both PSTs point out their lack of understanding of engineering design, as well as pedagogical knowledge needed for successfully integrating engineering design in their lessons.

\section{Resources Needed for Teaching Science through STEM Integration}

The participants expressed various ideas about types of resources they would need to successfully teach science through STEM integration. These ideas are summarized in Table 9.

Table 9.

Perceived Resources Needed for Teaching Science through STEM Integration

\begin{tabular}{lll}
\hline & Themes & Frequency \\
\hline & Need a course on STEM integration & 17 \\
& Need mentorship to get it right. & 11 \\
& Need professional development. & 17 \\
Resources needed to teach & Need feedback from an expert. & 14 \\
integrated STEM & With more practice, I can do a better job with & 9 \\
& designing a STEM lesson. & 15 \\
& Lab space and materials for engaging students un & 15 \\
hands-on STEM activities. & \\
\hline
\end{tabular}

Participants made several suggestions for addressing their professional needs to become prepared for the task of teaching through STEM integration. All participants were in agreement in taking a methods course focusing on STEM integration, needing mentorship and feedback from an expert on their lessons and practice and needing a lab space for engaging students in hands-on STEM activities. While they pointed out several challenges and highlighted their needs for resources, all of the participants but two were confident that their 
pedagogical skills for integrated STEM would improve with practice once they are in their classrooms. One PST expressed that taking a hands-on course on STEM integration would help her to become better prepared. She said:

I think I will greatly benefit from a course that taught us the engineering design process through handson activities. We could then apply our pedagogical knowledge to design engineering based integrated STEM lessons more easily for our students. I would feel more prepared to teach integrated STEM if I was provided with such learning experiences in my teacher preparation program.

Another PST said:

To develop better lessons, I will need resources, tools but also professional development in this area. For instance, I need to hear from my professors or colleagues about the weaknesses in my lessons, and get ideas from them about different aspects of my lessons. I believe with more practice and feedback; I will eventually be able to design quality integrated STEM lessons from my students.

Another PST expressed that having ready-made STEM lesson modules would help her to teach STEM more effectively than she could now without teacher-proof lessons.

I think I would prefer to have some ready-made lesson modules, with explanations both from a scientific, mathematical and pedagogical perspectives. These would help because I do not have a solid scientific or mathematical background. If I had these modules, I could self-learn the content before teaching it. I think some advanced training about pedagogy of STEM integration would also help but I am not sure if that training is available in schools.

Collectively, these statements show that PSTs believe that access to professional development both in content and pedagogy of integration and engineering design, and STEM related curricular resources would both help them to increase their efficacy to teach through STEM integration, and boost their pedagogical capacity to effectively integrate engineering design in their lessons.

\section{Discussion}

Research studies show that the way PSTs conceptualize STEM integration impacts how they integrate STEM content and engineering practices into their lessons and subsequently impacts what the students learn in the classroom (Diefes-Dux 2014; Estapa \& Tank, 2017; Yeung \& Lam, 2007; Guzey et al., 2016). The results show that PST's developed a "developing" understanding of STEM integration, and engineering design process. However, some of them struggled to transfer that understanding into pedagogical knowledge that held potential to promote students' acquisition of knowledge and skills aimed by integration. The PSTs experienced this struggle because they lacked a robust understanding of fundamental engineering knowledge and practices, had no experience in engineering design, and had limited content knowledge of science or mathematics.

Another important result that emerged from this study is that immersing PSTs in STEM integration activities, and guiding them to design STEM integration lessons brought about awareness regarding pedagogical demands of STEM integration and the gaps in their content knowledge. Our results also show that PST's became aware of the limitations of their conceptualizations of engineering design, importance of conceptual understanding of science and engineering design for effective integration, the need for professional development, and curriculum materials designed for purposeful integration. While their lessons reflected certain aspects of design-based STEM integration (as the interviews revealed), the majority of PSTs failed to make explicit references to the science/mathematical concepts that were the focus of the lesson. For instance, most of them only focused on the science content, ignoring the mathematoal connection. This is expected as primary school PSTs get limited opportunities (i.e., they take fewer number of science and math courses) to develop a sophisticated content knowledge needed to design content-heavy lessons. 
These results are consistent with relevant literature (Estapa \& Tank, 2017; Furner \& Kumar, 2007; Kim \& Bolger, 2017; Koirala \& Bowman, 2003). For instance, Estapa and Tank (2017) after engaging preservice elementary teachers in a semester long professional development, where they had a triad of PST, supervising teacher and an engineering graduate student work together, design, implement and reflect on engineering based STEM lessons, found that even after a 16-week intervention, teachers experienced unique challenges with implementation of engineering design activities. More specifically, they failed to effectively integrate science and math content into their lessons. In comparison to the 16-week intervention in Estapa and Tan (2017)'s study, we immersed PSTs in STEM integration activities for 6 weeks in the context of a university course with no room for implementation. We argue that if the PSTs had been given the opportunity to implement their lessons and were provided opportunity to engage in collaborative reflection under guidance of university faculty, they would have developed a better understanding of STEM integration and pedagogical skills to effectively integrate across STEM subjects. However, we understand that these results would be possible if PST's were convinced of the benefits of STEM integration, had content knowledge of science and math concepts that are the target of integration and engineering design process. Finally, we think that in order for PSTs and any teacher for that reason to develop sophisticated pedagogical knowledge and skills for STEM integration, they would need to engage in practice of teaching integrated STEM, and collaborative reflection for a sustained period of time. Engaging in such practice and reflection would encourage PSTs and practicing teachers to notice and reflect on what works and what does not work and develop more responsive instruction.

\section{Implications}

While the experiences provided helped students to be exposed to the idea of STEM integration, and engineering design process, these experiences alone are not sufficient for PSTs to effectively design integrated STEM lesson and meaningfully enact them in the classroom to promote students' acquisition of engineering knowledge and skills. The results of this study can inform efforts to design courses, professional development programs for pre-service primary and elementary teachers, the two groups that have limited content knowledge and experiences in engineering design, science and math content in general (Fung et al, 2017; Gomez-Zwiep, 2008). Literature suggests that professional development programs must engage teachers in active learning, focus on content, engage participants in collaborative inquiry and reflection (Borko, 2004, Borko, Jacobs, Eiteljorg \& Pittman. 2008; Garet, Porter, Desimone, Birman, \& Yoon, 2001; Gamoran, Secada, Marrett, 2006; Guzey et al. 2014; Loucks-Horsley, Hewson, Love, \& Stiles, 1997). However, with integration and engineering design being the new focus, new professional development models are called for. PSTs need not only learn about the content but also skills for purposeful and meaningful integration (Estapa \&Tank, 2017; Moore et al. 2014). Further, while doing so they must also help students acquire problem solving skills, and develop creative solutions through engineering design (Cunningham and Hester 2007; Guzey, Moore, \& Harwell, 2016). However, we know that majority of PSTs and practicing primary and elementary teachers have limited to no understanding of the engineering design process and skills associated with engineering practices (Hsu, Purzer, \& Cardella, 2011; Van Haneghan, Pruet, Neal-Waltman, \& Harlan, 2015). Therefore, we need not only make engineering design a central component of any professional development program but also, support teachers' implementation of STEM integration by providing them with curricular materials that use engineering design as the "organizing framework" for designing STEM-based learning experiences (Brophy et al. 2008; Cunningham and Lachapelle, 2014; Moore et al. 2014). Finally, curriculum materials designed in support of teachers' effective implementation of STEM activities, must come with educative curriculum materials for the teachers. These types of support mechanisms have been found to be useful for science teachers (Beyer \& Davis, 2009; Davis \& Krajcik, 2005). Moreover, professional development literature suggests that practice-based professional development programs create fruitful conditions for teachers to learn (Ball \& Cohen, 1999: Birman, Desimone, Porter, \& Garet, 2000). Therefore, we will follow these teachers into their classrooms and create diverse opportunities for them to learn about engineering design and pedagogy of STEM integration through collaborative inquiry and reflection in the form of lesson study (Lewis, 2002; Rock \& Wilson, 2005). We encourage STEM education community to 
think about ways in which pre-service primary teachers can be supported to develop content and pedagogy of integration. Similarly, we need to think about theoretical frameworks to conceptualize STEM integration pedagogy and practical tools to measure teachers' pedagogical knowledge related to STEM integration. 


\section{References}

Ball, \& D. L. \& Cohen, D. K. (1999). Developing practice, developing practitioners: Toward a practice-based theory of professional education. In Darling-Hammond, L. and G. Sykes. (Eds). Teaching as the Learning Profession (pp. 3-32): Handbook of Policy and Practice. San Francisco: Jossey Bass.

Baxter, J. A., Ruzicka, A., Beghetto, R. A. \& Livelybrooks, D. (2014). Professional development strategically connecting mathematics and science: the impact on teachers' confidence and practice. School Science and Mathematics, 114(3), 102-113.

Beane, J. A. (1995). Curriculum integration and the disciplines of knowledge. Phi Delta Kappan, 76(8), 616-622.

Bennett J., \& Holman J. (2002). Context-Based approaches to the teaching of chemistry: What are they and what are their effects?. In: Gilbert J.K., De Jong O., Justi R., Treagust D.F., Van Driel J.H. (eds) Chemical Education: Towards Research-based Practice. Science \& Technology Education Library, vol 17. Springer, Dordrecht

Berlin, D. F. \& Lee, H. (2005). Integrating science and mathematics education: historical analysis. School Science and Mathematics, 105(1), 15-24.

Beyer, C., \& Davis, E. A. (2009). Using educative curriculum materials to support preservice elementary teachers' curricular planning: A comparison between two different forms of support. Curriculum Inquiry, 39(5), 679-703.

Birman, B. F., Desimone, L. M., Porter, A. C., \& Garet, M. (2000). Designing professional development that works. Educational Leadership, 57(8), 28-33

Borko H. (2004). Professional development and teacher learning: Mapping the terrain. Educational Researcher, $33(8), 3-15$.

Borko, H., Jacobs, J., Eiteljorg, E., \& Pittman, M. E. (2008). Video as a tool for fostering productive discussions in mathematics professional development. Teaching and Teacher Education, 24, 417-436.

Brophy, S., Klein S, Portsmore, M., Rogers. C. (2008). Advancing engineering education in K-12 classrooms. Journal of Engineering Education, 97(3), 369-387.

Capraro, R.M., \& Slough, S.W. (2008). Project-based learning: An integrated science, technology, engineering, and mathematics (STEM) approach. Rotterdam, The Netherlands: Sense Publishers.

Cervetti, G. N., Barber, J., Dorph, R., Pearson, P. D. \& Goldschmidt, P. G. (2012), The impact of an integrated approach to science and literacy in elementary school classrooms. Journal of Research in Science Teaching, 49(5), 631-658.

Childress, V.W. (1996). Does integration technology, science, and mathematics improve technological problem solving: A quasi-experiment. Journal of Technology Education, 8(1), 16-26.

Clark, A.C., \& Ernst, J.V. (2006). A model for the integration of science, technology, engineering, and mathematics. The Technology Teacher, 66(4), 24-26.

Creswell, J. W. (1998). Qualitative inquiry and research design: Choosing among five traditions. London: Sage.

Coffey, A., \& Atkinson, P. (1996). Making sense of qualitative data. Thousand Oaks, CA: Sage Publications.

Crotty, M. (1998). The foundations of social research: Meaning and perspective in the research process. Sydney, NSW: Allen \& Unwin.

Cunningham, C. M., \& Lachapelle, C. P. (2014). Designing engineering experiences to engage all students. In S. Purzer, J. Strobel, \& M. Cardella (Eds.), Engineering in pre-college settings: synthesizing research, policy, and practices (pp. 117-142). Lafayette: Purdue University Press.

Cunningham, C. M., \& Hester, K. (2007). Engineering is elementary: an engineering and technology curriculum for children. Honolulu: Proceedings of the American Society for Engineering Education Annual Conference and Exposition. 
Diefes-Dux, H. A. (2014). In-service teacher professional development in engineering education: early years. In S. Purzer, J. Strobel, \& M. Cardella (Eds.), Engineering in precollege settings: Synthesizing Research, Policy, and Practices (pp 211-230). Lafayette: Purdue University Press.

Estapa, A. T., \& Tank, K.M (2017).Supporting integrated STEM in the elementary classroom: a professional development approach centered on an engineering design challenge. International Journal of STEM Education, 4(6), 1-16.

Frykholm, J., \& Glasson G. (2005). Connecting science and mathematics instruction: pedagogical context knowledge for teachers. School Science and Mathematics, 105(3), 127-141.

Fung, D., Kutnick, P., Mok, I., Leung, F., Lee, B. P. Y., Mai, Y. Y., \& Tyler, M. T. (2017). Relationships between teachers' background, their subject knowledge and pedagogic efficacy, and pupil achievement in primary school mathematics in Hong Kong: An indicative study. International Journal of Educational Research, 81, 119-130.

Furner, J. M. \& Kumar, D.D. (2007). The Mathematics and Science Integration Argument: A Stand for Teacher Education. Eurasia Journal of Mathematics, Science \& Technology Education, 3(3), 185-189.

Gamoran A., Secada W. G., Marrett C. B. (2000). The organizational context of teaching and learning: Changing theoretical perspectives. In Hallinan M.T. (Ed.), Handbook of research in the sociology of education (pp. 37-63). New York: Kluwer Academic/Plenum.

Garet, M. S., Porter, A. C., Desimone, L., Birman, B. F., \& Yoon, K. S. (2001). What makes professional development effective? Results from a national sample of teachers. American Educational Research Journal, 38(4), 915.

Gencer, S. A,. (2015). Fen Eğitiminde Bilim ve Mühendislik Uygulaması: Fırıldak Etkinliği. Araştırma Temelli Etkinlik Dergisi, 5(1), 1-19.

Gomez-Zwiep, S. (2008). Elementary teachers' understanding of students' science misconceptions: Implications for practice and teacher education. Journal of Science Teacher Education, 19, 437-454.

Guba, E. G., \& Lincoln, Y. S. (1994). Competing paradigms in qualitative research. In N.K. Denzin \& Y. S. Lincoln (Eds.), Handbook of qualitative research (pp 105-117). Thousand Oaks, CA: Sage Publications.

Gresnigt, R., Taconis, R., van Keulen, H., Gravemeijer, K \& Baartman, L. (2014). Promoting science and technology in primary education: a review of integrated curricula. Studies in Science Education, 50(1), 47-84.

Guzey, S. S., Moore, T. J., Harwell, M., \& Moreno, M. (2016). STEM Integration in Middle School Life Science: Student Learning and Attitudes. Journal of Science Education and Technology, 25(4), 550-560.

Guzey, S., Tank, K., Wang, H-H., Roehrig, G., and Moore, T. (2014). A High-Quality Professional Development for Teachers of Grades 3-6 for Implementing Engineering into Classrooms. School Science and Mathematics, 114(3), 139-149.

Guzey, S. S., Moore, T. J., \& Harwell, M. (2016). Building up STEM: An analysis of teacher-developed engineering design-based STEM integration curricular materials. Journal of Pre-College Engineering Education Research, 6(1), 11-29.

Harwell, M., Philips A, Mareno, M., Guzey SS, Moore T (2015) A study of STEM assessments in Engineering, Science, and Mathematics Assessments for elementary and middle school students. School Science and Mathematics, 115(2), 66-74.

Hsu, M-C; Purzer, S., \& Cardella, M. E. (2011). Elementary teachers' views about teaching Design, Engineering, and Technology. Journal of Pre-College Engineering Education Research (J-PEER), 1(2), 31-39.

Isaacs, A., Wagreich, P., \& Gartzman, M. (1997). The quest for integration: school mathematics and science. American Journal of Education, 106(1), 179-206, 
Kim, D., \& Bolger, M. (2017). Analysis of Korean elementary pre-service teachers' changing attitudes about integrated STEAM pedagogy through developing lesson plans. International Journal of Science and Mathematics Education, 15(4), 587-605.

Koirala, H. P. and Bowman, J. K. (2003), Preparing middle level preservice teachers to integrate mathematics and science: Problems and possibilities. School Science and Mathematics, 103(3), 145-154.

Lam, C. C., Alviar-Martin, T., Adler, S. A. \& Sim, J. B. (2013). Curriculum integration in Singapore: teachers' perspectives and practice. Teaching and Teacher Education, 31, 23-34.

Lehman, J., Kim, W., \& Harris, C. (2014). Collaborations in a community of practice working to integrate engineering design in elementary science education. Journal of STEM Education: Innovations and Research, 15(3), 21-28.

Lederman, N. G. \& Lederman, J. S. (2013). Is it STEM or "S \& M" that we truly love? Journal of Science Teacher Education, 24(8), 1237-1240.

Lehman, J. R. (1994). Integrating science and mathematics: perceptions of preservice and practicing elementary teachers. School Science and Mathematics, 94(2), 58-64.

Lewis, C. C. (2002). Lesson study: A handbook of teacher-led instructional change. Philadelphia: Research for Better Schools.

Loucks-Horsley, S., Hewson, P., Love, N., \& Stiles, K. (1997). Designing professional development for teachers of science and mathematics. Thousand Oaks, CA: Corwin Press.

Merriam, S. B. (2001). Qualitative research and case study applications in education. San Francisco: Jossey-Bass.

Miles, M., \& Huberman, A. M. (1994). Qualitative data analysis. Thousand Oaks, CA: Sage Publications.

Mobley, M. C. (2015). Development of the SETIS Instrument to measure teachers' self-Efficacy to teach science in an Integrated STEM Framework. PhD Dissertation, University of Tennessee, 2015.

Moore, T. J. (2008). STEM integration: Crossing disciplinary borders to promote learning and engagement. Invited presentation to the faculty and graduate students of the UTeach Engineering, UTeach Natural Sciences, and STEM Education program area at University of Texas at Austin, December 15, 2008.

Mostyn, B. (1985). The content analysis of qualitative research data: A dynamic approach. In M. Brenner, J. Brown \& D. Cauter (Eds.), The research interview (pp.115-145). London: Academic Press.Ring, E.A., Dare, E.A. Crotty, E. A., \& Roehrig, G.H. (2017) The evolution of Teacher conceptions of STEM Education throughout an intensive professional development experience, Journal of Science Teacher Education, 28 (5), 444-467.

Riskowski J. L, Todd C.D., Wee, B., Dark, M, \& Harbor, J. (2009). Exploring the effectiveness of an interdisciplinary water resources engineering module in eighth grade science course. International Journal of Engineering Education, 25(1), 181-195.

Rock, T. C. \& Wilson, C. (2005). Improving teaching through lesson study. Teacher Education Quarterly, 32(1), 77-92.

Roehrig, G. H., Moore, T. J.,Wang, H. \& Park, M. S. (2012). Is adding the E enough? Investigating the impact of K-12 engineering standards on the implementation of STEM integration. School Science and Mathematics, 112(1), 31-44.

Stohlmann, M., Moore, T. J., \& Roehrig, G. H. (2012). Considerations for teaching integrated STEM. Journal of Pre-College Engineering Education Research, 2(1), 28-34.

Sanders, M. E. (2008). STEM, STEMeducation, STEMmania. The Technology Teacher, 1, 20-26.

Stinson, K., Harkness, S., Meyer, H., \& Stallworth, J. (2009). Mathematics and science integration: Models and Characterizations. School Science and Mathematics, 109(3), 153-161. 
Van Haneghan, J. P., Pruet, S. A., Neal-Waltman, R., \& Harlan, J. M. (2015). Teacher beliefs about motivating and teaching students to carry out engineering design challenges: Some initial data. Journal of PreCollege Engineering Education Research, 5(2), 1-9.

Wendell K, \& Rogers, C. (2013). Engineering design-based science, science content performance, and science attitudes in elementary school. Journal of Engineering Education, 102(4), 513-540.

Yeung, S. Y. S. \& Lam, C. C. (2007). Teachers' conception of curriculum integration: a problem hindering its implementation in Hong Kong. Education Journal, 35(2), 109-144. 